\title{
Hubungan Akhlak dengan Hasil Belajar pada Mata Pelajaran Pendidikan Agama Islam
}

\author{
Apriyanda ${ }^{1}$, Sulaiman ${ }^{2}$ \\ apriyanda1203@gmail.com ${ }^{1}$, sulaiman@fis.unp.ac.id ${ }^{2}$ \\ Universitas Negeri Padang ${ }^{1,2}$
}

\begin{tabular}{l}
\hline ARTICLE INFO \\
\hline Article history: \\
Received, 24 August 2021 \\
Revised, 11 November \\
2021 \\
Accepted, 30 November \\
2021 \\
\hline
\end{tabular}

\section{Keywords:}

Akhlak, Hasil Belajar,

Pendidkan Agama Islam

\section{Clonflict of Interest:}

None

\section{Funding:}

None

\section{ABSTRACT}

Penelitian ini bertujuan untuk mengetahui hubungan akhlak siswa dengan hasil belajar pada mata pelajaran pendidikan agama Islam di SMPN 1 Sembilan Koto Kabupaten Dharmasraya. Jenis Penelitian ini merupakan penelitian lapangan (Field Research) dengan pendekatan metode penelitian kuantitatif. Populasi penelitian ini adalah seluruh peserta didik kelas VII SMPN 1 Sembilan Koto Kabupaten Dharmasraya dengan jumlah 60 orang. Sampel dari penelitian ini diambil dengan teknik total sampling, dengan jumlah sampel sebanyak 60 orang. Pengumpulan data dilakukan dengan teknik angket dan dokumentasi. Untuk pengujian hipotesis menggunakan rumus dengan bantuan program SPSS versi 25 diperoleh rxy 0,524 sedangkan $r$-tabel dengan $n=60$ adalah 0,254 . karena r-hitung $(0,524)$ lebih besar dari pada r-tabel $(0,254)$, maka Ha diterima dan Ho ditolak. Jadi terdapat hubungan yang positif dan signifikan antara akhlak siswa dengan hasil belajar PAI Siswa Kelas VII di SMPN 1 Sembilan Koto Kabupaten Dharmasraya Tahun Ajaran $2020 / 2021$.

Corresponding Author: Apriyanda, Department Islamic Education Faculty of Social Science Universitas Negeri Padang, Indonesia, Email: apriyanda1203@gmail.com Phone: +62812-7515-5696

Copyright@ 2021, Author(s)

\section{Pendahuluan}

Perspektif pendidikan di Indonesia menjelaskan bahwa pendidikan berada di bawah naungan kementerian dengan ruang lingkup tertentu. Kementerian Agama yang mencakup pada pendidikan agama dan Kementerian Pendidikan Nasional yang cakupannya pada pengetahuan umum. Walaupun kedua institusi tersebut mempunyai cakupan yang berbeda namun pada dasarnya mempunyai tujuan yang sama, yaitu sebagaimana dituangkan dalam Undang-undang No.20 Tahun 2003 Pasal 3 Tentang Sistem Pendidikan Nasional, tentang Tujuan Pendidikan Nasional adalah: "untuk mengembangkan potensi peserta didik agar menjadi manusia yang beriman dan bertakwa kepada Tuhan Yang Maha Esa, berakhlak mulia, sehat, berilmu, cakap, kreatif, mandiri, dan menjadi warga negara yang demokratis serta bertanggung jawab".

Permendiknas Nomor 211 Tahun 2011 dalam keputusan Menteri menyebutkan bahwa Pendidikan agama Islam ialah suatu proses pendidikan yang memberikan ilmu pengetahuan dan membentuk sikap, kepribadian, serta keterampilan peserta didik dalam menerapkan nilai-nilai yang telah diajarkan dalam proses pembelajaran agama Islam. Proses pembelajaran pendidikan agama Islam dilakukan sekurang-kurangnya melalui semua mata 
pelajaran pada semua jenjang pendidikan. Pendidikan agama ini berfungsi untuk membentuk manusia yang berkarakter, beriman dan bertaqwa kepada Allah SWT serta berakhlak mulia agar tercipta kemakmuran dan perdamaian (Permendiknas, 2011).

Tujuan utama dari pendidikan agama Islam yaitu menciptakan kerukunan, keharmonisan, serta menumbuhkan karakter dan sikap peserta didik yang jujur, disiplin, dapat di percaya, kerja keras, independen, kompetisi, kerjasama, ikhlas, percaya diri serta bertanggung jawab. Pendidikan agama Islam bertujuan untuk mengembangkan semua aspek hukum Islam yaitu akidah, syari'ah dan akhlak. Maksud akidah yaitu sesuatu yang berhubungan dengan kepercayaan mengenai ajaran Islam. Adapun syari'ah berhubungan dengan penerapan ajaran Islam. Sedangkan akhlak merupakan perangai, karakter dan tingkah laku seperti yang ditetapkan dalam Islam (Hasanah, 2017).

Pada tingkat satuan pendidikan dilakukan suatu evaluasi pembelajaran dengan tujuan mengukur bagaimana tingkat keberhasilan suatu pembelajaran. Tingkat keberhasilan sebuah proses pembelajaran biasanya ditandai dengan hasil belajar yang dicapai oleh siswa. Hasiil belajar pembelajaran Pendidikan Agama Islam mempunyai keterkaitan terhadap perilaku atau akhlak. Dengan kata lain seorang siswa yang memperoleh capaian hasil belajar yang baik, maka akan senantiasa menunjukkan perilaku atau akhlak mulia, baik lingkungan keluarga, lingkungan sekolah, serta di lingkungan masyarakat sekitar. Maka idealnya siswa yang mempunyai akhlak yang baik, juga memiliki pencapaian hasil belajar yang baik. Akhlak atau sikap seseorang akan memberikan corak dalam bertingkah laku terutama dalam belajar. Apabila perilaku yang ditunjukkan oleh siswa positif maka itu adalah awal yang baik bagi siswa dalam mencapai tujuan pembelajaran. Hal ini bisa memberikan dampak atas hasil belajar siswa di sekolah (Djaali, 2013).

Peran pendidikan khususnya pendidikan agama Islam sangat besar pengaruhnya terhadap pembentukkan karakter peserta didik. Pendidikan karakter merupakan cara untuk mentransformasikan pengetahuan peserta didik tentang aspek agama (aspek kognitif), cara untuk mengubah norma dan nilai moral dengan membentuk sikap (aspek afektif) memainkan peran kontrol dan sikap peserta didik (aspek psikomotorik) sehingga terciptanya kepribadian manusia yang baik dan patuh terhdapat norma-norma yang berlaku (Ainiyah, 2013).

Belajar adalah suatu bagian yang terpenting dalam proses memperoleh ilmu pengetahuan pada lembaga pendidikan formal, informal dan non formal. Menurut Suyono dan Harianto (2012) mengemukakan bahwa Belajar ialah suatu kegiatan, pekerjaan atau proses yang bertujuan memperoleh pengetahuan, melatih keterampilan, memperbaiki aklak/ perilaku, dan membentuk kepribadian. Jadi belajar dapat diartikan sebagai interaksi yang dilakukan secara sadar antara pendidik dengan peserta didik, hubungan terencana baik didalam ruangan maupun di luar ruangan untuk memperoleh pengetahuan, perilaku dan keterampilan peserta didik yang ditentukan oleh hasil belajar.

Menurut Hamalik (2012) hasil belajar adalah proses perubahan perilaku pada individu seseorang dari ketidaktahuan menjadi tahu, dari tidak mengerti hingga mengerti, dari belum paham menjadi paham serta dari belum mampu menjadi mampu. Hasil belajar bisa terlihat dalam bermacam aspek yaitu: pengetahuan, keterampilan, apresiasi, kondisi mental, interaksi sosial, keadaan jasmani, kebiasaan, etika atau perilaku dalamn bersikap. Seseorang yang sudah melewati proses belajar maka akan tampak perubahan yang terjadi pada suatu atau bebarapa aspek perilaku sebagai dampak dari hasil belajar. Hasil belajar yang diperoleh siswa tidak dapat dicapai dengan mudah, namun ada faktor penilaian diantaranya perilaku/ akhlak.

Menurut Ibnu Miskawaih (dalam Jamal, 2017) akhlak adalah kondisi jiwa seseorang individu yang mengajak dan menuntun untuk mengerjakan suatu tindakan lansung tanpa memerlukan banayak pertimbangan. Artianya, perbuatan seorang individu itu spontan dan bersumber dari kondisi jiwa atau psikologis. Kondisi jiwa berupa fitrah alamiah atau bawaan dan bertolakbelakang dengan watak yang berupa pembiasaan diri serta dengan hasil latihan. Oleh karena itu, jika jiwa diarahkan pada suatu yang baik maka hasil yang diperoleh ialah 
Apriyanda dan Sulaiman: Hubungan Akhlak dengan Hasil Belajar pada...

akhlak yang baik, dan sebaliknya jika jiwa darahkan pada suatu yang tidak baik maka menimbulkan perbuatan tidak baik atau tercela.

Sumber dasar hukum Islam yaitu Alquran dan Hadits Nabi Muhammad SAW juga banyak disebutkan urgensi dan signifikasi dalam pendidikan agama Islam, seperti firman Allah SWT, yakni: "Niscaya Allah akan meninggikan orang-orang yang beriman diantaramu dan orangorang yang berilmu pengetahuan beberapa derajat". (Al Mujadalah [58]:11). Dalam firman Allah SWT tersebut terkandung makna pentingnya pengetahuan di dalam agama Islam. Pengetahuan dapat diperoleh dengan proses pendidikan sehingga dampak dari pendidikan itu adalah akhlak mulia sejalan dengan tujuan pendidikan. Hal ini sejalan dengan tujuan Pendidikan Agama Islam yang meletakkan pembentukan akhlak mulia pada urutan yang utama.

Setelah penulis melakukan wawancara dengan Ibu Rosnawenti guru mata pelajaran Pendidikan Agama Islam di SMP Negeri 1 Sembilan Koto, dijelaskan bahwa proses pembelajaran Pendidikan Agama Islam selalu dilaksanakan sesuai dengan standar dan ketentuan yang berlaku. Namun pada kenyataannya hasil belajar siswa dalam pembelajaran Pendidikan Agama Islam cenderung rendah, perolehan hasil belajar siswa rata-rata yaitu 62, sedangkan nilai minimum untuk mencapai ketuntasan matapelajaran Pendidikan Agama Islam ialah 65. Hal tersebut dipengaruhi oleh proses penilaian hasil belajar yang berpatokan pada ketentuan yang berlaku dalam kurikulum 2013 bahwasanya penilaian yang utama adalah aspek Afektif. Artinya jika seorang siswa ia mempunyai akhlak yang baik namun pencapaian hasil belajar kurang baik, maka akhlak bisa menjadi pertimbangan untuk mengangkat nilai hasil belajar matapelajaran Pendidikan Agama Islam dan begitu sebaliknya.

Dari pengamatan awal dan wawancara singkat dengan orang tua siswa, diketahui terdapat beberapa siswa yang tidak berperilaku baik kepada orang tua, contohnya tidak mematuhi perintah orang tua dan berbicara dengan nada tinggi. Kemudian tidak berprilaku baik kepada guru contohnya berbicara tidak sopan dan suka membuat guru marah. Dan juga kepada teman sebaya serta lingkungan masyarakat seperti berkelahi, merusak fasilitas umum dan membuat kebisingan saat orang beribadah. Maka berdasarkan permasalahan diatas, penulis tertarik untuk mengadakan penelitian dengan judul penelitian "Hubungan Akhlak Siswa dengan Hasil Belajar Pendidikan Agama Islam Siswa Kelas VII di SMP Negeri 1 Sembilan Koto Kabupaten Dharmasraya".

\section{Tinjauan Pustaka}

Akhlak secara bahasa (etimologi) berasal dari bahasa arab yaitu al-akhlak (الَْخْلَقَ) kata tersebut merupakan jamak dari kata khuluq (خُقْقُ) yang artinya perangai, tingkah laku, atau bawaan atau tabiat (Jumhuri, 2015). Kata Akhlak juga berarti perangai, tabiat, adat atau khalakun yang berarti kejadian penciptaan manusia, buatan ciptaan. Jadi akhlak atau perilaku ialah perangai, budi pekerti, adat kebiasaan, muru'ah, atau sesuatu perbuatan yang sudah menjadi bawaan atau tabi'at. Perbuatan baik atau buruk yang dilakukan oleh manusia bisa bergantung pada nilai-nilai yang tertanam dalam dirinya kemudian diamalkan sebagai landasan perbuatan (Abuddin, 2015).

Sedangkan secara istilah (terminologi) Akhlak berarti perbuatan seseorang secara sadar yang didorong oleh suatu keinginan untuk melakukan suatu tindakan yang baik dengan tidak memerlukan banyak pertimbangan serta pemekiran terlebih dahulu (Jumhuri, 2015). Ada beberapa pendapat ahli tentang defenisi akhlak diantaranya:

Menurut Imam Al-Ghazali (dalam Badrudin, 2015) akhlak adalah: "Akhlak adalah sifat yang melekat dalam jiwa (manusia) yang melahirkan perbuatan-perbuatan dengan mudah tanpa memerlukan pemikiran maupun pertimbangan tertentu". Menurut Ibnu Miskawaih dalam (Jamal, 2017) akhlak adalah kondisi jiwa yang menndorong serta mengjak seseorang untuk melakukan suatu perbuatan tanpa harus difikirkan dan diper-hitungkan. Dapat dipahami bahwa perbuatan yang dilakukan itu spontan dan berasal dari keadaan jiwa yang merupakan sumber dari segala perbuatan baik ataupun buruk. Perbuatan tersebut dapat 
berupa bawaan atau fitrah alamiah dan bertolak dari watak yang merupakan hasil latihan serta pembiasaan dalam diri. Oleh Karena itu, jika jiwa diarahkan pada suatu kebaikan maka efek yang akan ditimbulkan berupa akhlak yang baik, tetapi apabila jiwa diarahkan pada keburuakan akan menyebabkan perbuatan tercela.

Sementara itu menurut Syaikh Utsaimin yang dikutip oleh Hawassy ( 2020) akhlak adala sifat yang tertanam didalam diri seseorang yang membuat segala perbuatan yang dilakukannya baik atau buruk, tercela atau tidak tercela bergantun pada akhlak. Pada hakikatnya akhlak merupakan keadaan batin seseorang dan sifat yang sebenarnya dari seseorang.

Beberapa definisi tersebut bisa disimpulkan bahwa: Pertama, akhlak adalah perbuatan yang telah tertanam dalam jiwa, sehingga telah menjadi suatu kepribadian. Kedua, perbuatan itu dilakukan secara konstan serta dilakukan berulang-ulang dalam bentuk perbuatan yang sama, sehingga dapat dikatakan sudah menjadi kebiasaan. Ketiga, akhlak merupakan perbuatan yang muncul tanpa adanya suatu unsur paksaan ataupun tekanan dari pihak lain. Keempat, akhlak merupakan perbuatan yang dilakukan dengan sepenuh hati, ikhlas dan tanpa adanya suatu sandiwara atau pencitraan.

Akhlak yang baik dan benar akan terbentuk apabila sumbernya benar. Sumber akhlak yang paling utama adalah Agama. Karena akhlak merupakan pantulan dari keadaan keimanan seseorang yang terlihat dalam tindakan dalam kehidupan sehari-hari. Peran Agama dalam membina akhlak manusia terlihat dalam ketentuan sumber hukum Islam yaitu firman Allah (Al-Quran) dan As-Sunnah. Sehingga tolak ukur perbuatan baik atau buruk, pantas atau tidak pantas ialah Al-Quran dan As-Sunnah (Munirah, 2017).

Ruang lingkup yang menjadi Objek pembahasan akhlak ialah berkaitan dengan norma atau penilaian terhadap suatu perbuatan yang dilakukan oleh seseorang. Jadi ruang lingkup akhlak adalah membahas tentang perbuatan atau tindakan manusia, kemudian mengkategorikan apakah perbuatan tersebut tergolong perbuatan yang terpuji atau perbuatan yang tercela (Abuddin, 2015).

Menurut Ahmad Hawassyi (2020) ruang lingkup akhlak meliputi : Allah dan Rasul-Nya. Lebih jelasnya bahasan akhlak mencakup berbagai aspek berikut: Akhlak kepada Allah SWT, Akhlak kepada Rasulullah SAW, Akhlak terhadap Diri sendiri, Akhlak terhadap Orang lain (meliputi sesama muslim dan orang kafir), Akhlak kepada Keluarga (meliputi orang tua, istri/suami, anak, dan kerabat keluarga), Akhlak dalam masyarakat (meliputi tetangga dan tamu), Akhlak terhadap lingkungan (meliputi alam, hewan dan tumbuhan) serta Akhlak sebagai pemimpin orang yang dipimpin.

Menurut Nurhasan (2018) ruang lingkup akhlak terbagi atas dua kelompok yaitu: akhlak kepada pencipta (khaliq) dan akhlak kepada ciptaan (makhluk). Akhlak terhahadap ciptaan Allah SWT (makhluk) masih dirinci lagi menjadi beberapa aspek, seperti akhlak terhadap sesama manusia, akhlak terhadap makhluk hidup selain manusia yaitu tumbuhan dan binatang, serta akhlak terhadap benda mati.

Berdasarkan uraian di atas akhlak siswa sejalan dengan nilai-nilai pendidikan karater menurut Peraturan Kementerian Pendidikan Nasional yang terdiri atas 18 indikator, yaitu: Religius, Toleransi, Jujur, Kerja Keras, Disiplin, Kreatif, Mandiri, Demokratis, Rasa Ingin Tahu, Semangat Kebangsaan, Cinta Tanah Air, Menghargai Prestasi, Bersahabat/Komunikatif, Cinta Damai, Gemar Membaca, Peduli Lingkungan, Peduli Sosial, dan Tanggung Jawab. Keseluruhan aspek tersebut juga berhubungan dengan hasil belajar siswa.

Menurut Afandi (2013) Hasil belajar adalah sebuah proses berubahnya kemampuan intelektual (kemampuan kognitif), kemampuan emosi dan sikap (kemampuan afektif) serta kemampuan keahlian atau keterampilan (psikomotor) pada peserta didik. Dalam satuan pendidikan dasar diharapkan Perubahan kemampuan peserta didik sesuai dengan tahap pekembangannnya yaitu pada tahapan operasional kongrit. Dari pengertian tersebut dapat diartikan bahwa hasil belajar adalah apa yang diperoleh setelah melakukan belajar yang meliputi aspek pengetahuan (kognitif), perilaku atau sikap (afektif) dan keterampilan (psikomotor). 
Apriyanda dan Sulaiman: Hubungan Akhlak dengan Hasil Belajar pada...

Menurut Parwati (2018) faktor yangbisa mempengaruhi hasil belajar terbagi atas dua faktor, yaitu faktor internal dan eksternal. Faktor Internal merupakan faktor yang berasal dari dalam diri individu yang dapat mempengaruhi hasil belajar. Diantara faktor internal tersebut meliputi (1) Faktor Fisiologis yaitu faktor yang berkaitan dengan kondisi fisik individu, (2) Faktor Psikologis yaitu kondisi jiwa seseorang yang dapat memengaruhi proses belaja seperti kepintaran siswa, motivasi, minat, perilaku, keterampilan dan percaya diri, (3) Faktor Kelelahan yaitu kelelahan fisik atau jasmani dan rohani (psikis).

Faktor Eksternal di antaranya: (1) Keluarga, faktor Keluarga akan lebih dahulu memberikan pengaruh kepada Siswa dalam belajar berupa cara orang tua mendidik, suasana rumah tangga, hubungan antara anggota keluarga, dan kondisi ekonomi keluarga. (2) Faktor sekolah, yang bisa memengaruhi belajar ini mencakup: Metode Mengajar, Metode Belajar, Kurikulum, Hubungan Guru dengan siswa, Hubungan siswa dengan siswa, Kedisiplinan di Sekolah, Alat dan media Pembelajaran, Jumlah jam belajar, Tingginya standar materi pelajaran, Kondisi sarana dan prasarana, Tugas tambahan bagi siswa atau pekerjaan dirumah. (3) Faktor masyarakat seperti: Kegiatan Siswa di lingkungan Masyarakat bisa memberikan perubahan terhadap perkembangan sikap dan kepribadiannya, Media Massa bisa mempengaruhi hasil belajar siswa seperti: radio, TV, surat kabar, majalah, buku-buku, dan sosial media. (4) Teman bergaul, teman bergaul juga berperan memberikan dampak terhadap diri siswa. (5) Bentuk ekhidupan masyarakat juga bisa memberikan pengaruh terhadap proses serta hasil belajar siswa.

Hasil belajar juga bisa dipengaruhi oleh lingkungan belajar. Salah satu lingkungan belajar yang paling berpengaruh seperti kualitas pengajaran. Yang dimaksud dengan kualitas pengajaran adalah tinggi rendahnya serta efektif atau tidaknya proses pembelajaran. Jadi semakin tinggi kualitas pembelajaran, maka akan semakin tinggi hasil belajar yang diperoleh siswa (Sudjana, 2014).

Berdasarkan penjelasan di atas dapat disimpulkan bahwa faktor yang mempengaruhi hasil belajar siswa ada dua faktor, yaitu faktor internal (faktor dari dalam diri siswa) dan faktor eksternal (faktor yang berasal dari luar diri siswa). Selain itu juga dipengaruhi oleh kualitas pembelajaran dan kemampuan siswa.

Penilaian hasil belajar siswa dilakukan dengan berbagai teknik dan cara sesuai dengan kompetensi yang ingin dinilai. Kriteria penilaian kompetensi sikap dilakukan dengan kegiatan observasi, penilaian diri, penilaian antar teman dan jurnal. Kriteria penilaian kompetensi pengetahuan dilakukan dengan kegiatan tes tulis, tes lisan, dan penugasan. Kriteria penilaian kompetensi keterampilan dilakukan melalui penilaian kemampuan berupa kerja praktik, dan penilaian portofolio (Wiratma, 2016).

Dapat disimpulkan bahwa penilaian hasil belajar adalah suatu kegiatan dalam dunia pendidikan yang bertujuan untuk mengetahui sejauh mana tercapainya tujuan pendidikan oleh siswa, yang meliputi aspek pengetahuan (kognitif), sikap (afektif) dan keterampilan (psikomotor). Penilaian hasil belajar tersebut ditunjukkan dengan hasil evaluasi dalam bentuk nilai-nilai rapor. Dalam penelitian ini nilai rapor yang diambil adalah hasil Ujian Tengah Semester (UTS Mata Pelajaran PAI).

Pendidikan agama Islam ialah sebuah sarana pemerolehan pengetahuan dalam berbagai aspek baik aspek pengetahuan keagamaan (aspek kognitif), perubahan moral dan sikap (aspek afektif), dan prilaku individu (aspek psikomotorik) sehingga terbentuknya kepribadian manusia yang berakhlak mulia sesuai nilai-nilai ajaran agama Islam (Ainiyah, 2013).

Menurut Arifin (2011) Pendidikan agama Islam bertujuan agar setiap umat Muslim manpu memahami, menghayati, dan mengamalkan ajaran islam sesuai dengan iman dan akidah islamiah. Kemudian supaya umat Islam mampu menciptakan kedamaian dan kesejahteraan sebagai cita-cita yang diharapkan.

Izharman (2018) menjelaskan tujuan Pendidikan Agama Islam adalah untuk mendidik ahklak siswa dari yang belum bernuansa islami menjadi bernuansa islami melalui proses 
teori dan praktek. Proses pencapaian tujuan Pendidikan Agama Islam dilakukan dengan memperhatikan tingkat pertumbuhan dan perkembangan siswa.

Secara umum penelitian ini bertujuan untuk mengetahui hubungan akhlak siswa dengan hasil belajar Pendidikan Agama Islam Siswa Kelas VII Di SMP Negeri 1 Sembilan koto Kabupaten Dharmasraya.

\section{Metode}

Jenis penelitian termasuk kedalam jenis penelitian lapangan (Field Research) dengan pendekatan kuantitatif. Metode penelitian pada penelitian ini menggunakan metode korelasional. Variabel pada penelitian ini terdiri atas variabel bebas dan variabel terikat. Variabel bebas pada penelitian ini yaitu akhlak siswa yang diberi tanda X dan variabel terikat pada penelitian ini adalah hasil belajar PAI yang diberi tanda Y. Populasi pada penelitian ini adalah keseluruhan siswa kelas VII SMP Negeri 1 Sembilan Koto Kabupaten Dharmasraya yang berjumlah 60 orang siswa. Tenik pengambilan sampel sampling pada penelitian ini yakni seluruh populasi dijadikan sebagai sampel (Total Sampling). Teknik pengumpulan data menggunakan angket dan dokumentasi. Instrumen penelitian yang digunakan adalah angket akhlak siswa dan Rapor hasil ujian tengah semestes siswa. Uji validitas dengan rumus product moment dan reliabilitas dengan rumus Alpha Crounbach menggunakan program SPSS versi 25. Untuk mendapatkan hasil dari penelitian ini penulis menyebarkan angket secara langsung kepada siswa kelas VII dengan 60 responden. Untuk melakukan analisis data penulis menggunakan Microsoft Exel dan Program SPSS Versi 25.

\section{Hasil dan Pembahasan}

Data akhlak siswa dalam penelitian ini diperoleh dengan metode angket skala likert yang memuat kisi-kisi indikator akhlak siswa. Adapun angket skala likert digunakan untuk mengukur sikap, persepsi/ presepsi seseorang atau sekelompok orang tentang fenomena sosial. Lalu dengan menggunakan angket skala likert, maka variabel yang akan diukur dijabarkan menjadi indikator variabel. Kemudian indikator tersebut dijadikan sebagai tolak ukur untuk menyusun item-item instrumen yang dapat berupa pernyataan atau pertanyaan. Sedangkan data hasil belajar siswa diperoleh dari nilai rapor ujian tengah semester mata pelajaran Pendidikan Agama Islam siswa.

Dari penelitian yang telah dilakukan di SMP Negeri 1 Sembilan Koto Kabupaten Dharmasraya. Hasil analisis nilai angket akhlak siswa yang telah diberikan kepada 60 responden, diperoleh data nilai akhlak siswa segai berikut: Responden $(\mathrm{N})=60$ dengan data terendah $(\operatorname{Min})=51$, dan data tertinggi $($ Max $)$ 91, rata-rata $($ Mean $)=69$, median $(\mathrm{Md})=$ 68,78 , modus $(\mathrm{Mo})=68$, standar deviasi $(\mathrm{SD})=10.286$. Data terergolong kedalam kategori data interval dengan Range $(R)=40$. Untuk mengetahui lebih jelas temuan tentang variabel Akhlak Siswa bisa dilihat hasil analisis pada tabel berikut:

Tabel 1. Distribusi Frekuensi kategori Akhlak Siswa

\begin{tabular}{|c|c|c|c|c|}
\hline & Ko & $\boldsymbol{i}=\mathbf{1 3}$ & $\boldsymbol{F}$ & $\%$ \\
\hline $\mathbf{1}$ & Tinggi & $79-91$ & 13 & 21,7 \\
\hline $\mathbf{2}$ & Sedang & $65-78$ & 24 & 40,0 \\
\hline $\mathbf{3}$ & Rendah & $51-64$ & 23 & 38,3 \\
\hline & & Total & $\mathbf{6 0}$ & $\mathbf{1 0 0} \%$ \\
\hline
\end{tabular}

Dari tabel distribusi tersebut diketahui bahwa akhlak Siswa kelas di VII SMP Negeri 1 Sembilan Koto Kabupaten Dharmasraya berada pada kategori kurang baik sebanyak 23 siswa atau $38,3 \%$, dalam kategori kurang baik sebanyak 24 siswa atau $40 \%$ dan dalam kategori cukup baik sebanyak 13 siswa atau 21,7\%. Sehingga didapat bahwa data Akhlak Siswa kelas VII SMP Negeri 1 Sembilan Koto Kabupaten Dharmasraya tahun ajaran 2020/2021 sebagian besar berada pada kategori sedang/ cukup baik seperti terlihat pada histogram berikut: 
Apriyanda dan Sulaiman: Hubungan Akhlak dengan Hasil Belajar pada...

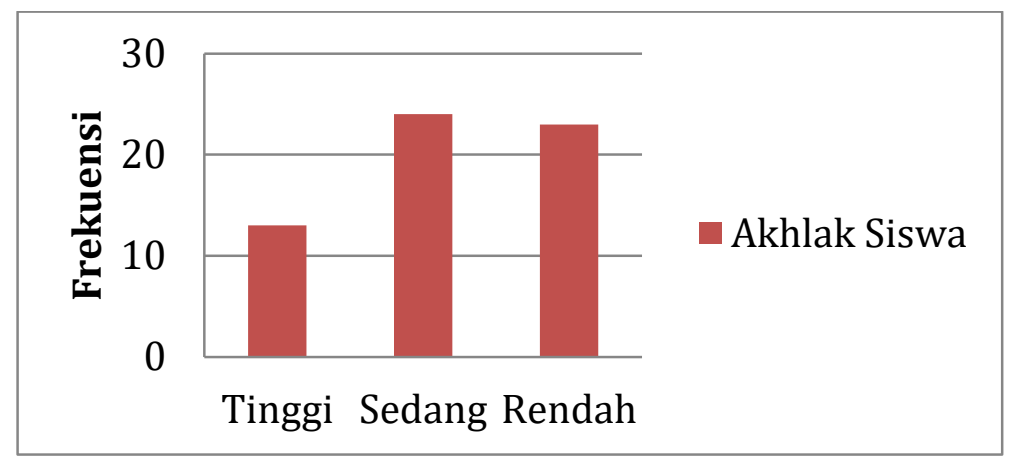

Gambar 1. Histogram Nilai Akhlak Siswa

Data hasil belajar Pendidikan Agama Islam siswa kelas VII SMP Negeri 1 Sembilan Koto Kabupaten Dharmasraya diperoleh: Responden $(\mathrm{N})=60$ dengan data terendah $(\mathrm{Min})=50$, dan data tertinggi $(\mathrm{Max}) 100$, rata-rata $($ Mean $)=73,67$, median $(\mathrm{Md})=70$, $\operatorname{modus}(\mathrm{Mo})=80$, standar deviasi $(\mathrm{SD})=11.156$. Data terergolong kedalam kelas interval dengan Range $(\mathrm{R})=$ 50. Untuk mengetahui gambaran tentang data temuan variabel hasil belajar mata pelajaran Pendidikan Agama Islam siswa dijelaskan pada tabel berikut:

\begin{tabular}{|c|c|c|c|c|}
\hline \multirow{2}{*}{ Tabel 2. Distribusi Frekuensi kategori Hasil belajar PAI Siswa } \\
\hline No & Kategori & $\boldsymbol{i}=\mathbf{1 7}$ & $\boldsymbol{f}$ & $\%$ \\
\hline $\mathbf{1}$ & Tinggi & $86-100$ & 5 & 8,3 \\
\hline $\mathbf{2}$ & Sedang & $68-85$ & 36 & 60,0 \\
\hline $\mathbf{3}$ & Rendah & $50-67$ & 19 & 31,7 \\
\hline & & Total & 60 & 100 \\
\hline
\end{tabular}

Berdasarkan data tabel distribusi di atas, bisa diketahui bahwa hasil belajar pendidikan agama Islam siswa kelas VII di SMP Negeri 1 Sembilan Koto Kabupaten Dharmasraya berada pada kategori rendah sebanyak 19 siswa atau 31,7\%, dalam kategori sedang sebanyak 36 siswa atau 60\%, dan sebanyak 5 siswa atau 8,3\% dalam kategori tinggi. Dari hasil tersebut diketahui bahwa Hasil belajar Pendidikan Agama Islam siswa kelas VII di SMP Negeri 1 Sembilan Koto Kabupaten Dharmasraya tahun ajaran 2020/2021 sebagian besar terdapat pada kategori sedang seperti terlihat pada histogram berikut:

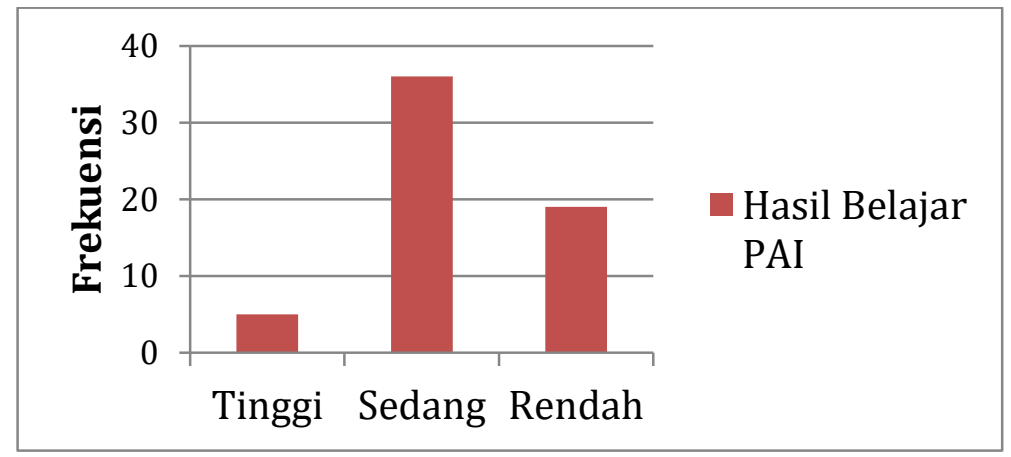

Gambar 2. Histogram Nilai PAI Siswa

Untuk mengetahui tingkat hubungan antara akhlak siswa hasil belajar pendidikan agama Islam siswa kelas VII di SMP Negeri 1 Sembilan Koto Kabupaten Dharmasraya maka dilakukan uji hipotesis. Uji hipotesis dalam penelitian ini menggunakan teknik korelasi product moment. Uji hipotesis dilakukan dengan bantuan program SPSS versi 25. Untuk 
kriteria hasil uji hipotesis dalam penelitian ini diketahui dengan melihat output pearson correlation dan nilai sig. (2-tailed). Jika nilai pearson correlation $>r$-tabel maka dinyatakan berkorelasi. Jika nilai sig. $<0,005$ maka dinyatakan tidak berkorelasi. Dari hasil analisis didapat $r$-hitung $=0,524$. Sedangkan $r$-tabel untuk responden $(N)=60$ adalah 0.254 . Karena $r$ hitung 0,524 besar dari r-tabel 0.254, maka Hipotesis Awal (Ha) diterima dan Hipotesis nihil (Ho) ditolak. Jadi diketahui bahwa data memiliki hubungan yang signifikan. Artinya semakin tinggi nilai akhlak siswa maka akan semakin tinggi capaian hasil belajar Pendidikan Agama Islam Siswa.

Dari hasil analisis data penelitian akhlak siswa berada pada kategori sedang. Artinya siswa sudah menjalankan nilai-nilai akhlak yang baik dalam kehidupan sehari-hari baik dari apek akhlak kepada Allah SWT, akhlak terhadap sesama manusia dan akhlak terhadap lingkungan. Namun belum seluruh siswa menerapkan nilai akhlak yang baik secara menyeluruh dalam bertindak seperti siswa suka menolong orang lain dan menjaga kelestarian lingkungan di suatu sisi malas beribadah dan kurang menurut terhadap orang tua atau guru dan juga sebaliknya. Jadi dapat dikatakan akhlak siswa berada pada katergori sedang atau cukup baik.

Akhlak yang baik memiliki kedudukan yang sangat penting dalam individu atau kehidupan bermasyarakat terkhususnya pada siswa kelas VII SMP Negeri 1 Sembilan Koto Kabupaten Dharmasraya. Apa yang didapat oleh siswa dalam lingkungannya akan dibawa untuk diterapakan di lingkungan belajar di sekolah maupun dalam pergaulannya. Hal ini bisa memberikan pengaruh atau dampak terhadap perolehan hasil belajar siswa khususnya di SMP Negeri 1 Sembilan Koto Kabupaten Dharmasraya. Hal ini sejalan menurut Djaali (2013) bahwa Akhlak atau sikap seseorang akan memberikan corak dalam bertingkah laku terutama dalam belajar. Apabila perilaku yang ditunjukkan oleh siswa positif maka itu adalah awal yang baik bagi siswa dalam mencapai tujuan pembelajaran. Hal ini bisa memberikan dampak atas hasil belajar siswa di sekolah.

Hasil belajar merupakan wujud dari usaha yang telah dilakukan siswa dalam kegiatan belajar mengajar yang ditempuhnya. Sejalan dengan pendapat Afandi (2013) Hasil belajar adalah sebuah proses berubahnya kemampuan intelektual (kemampuan kognitif), kemampuan emosi dan sikap (kemampuan afektif) serta kemampuan keahlian atau keterampilan (psikomotor) pada peserta didik.

Dari data hasil penelitian yang diperoleh, bahwa semakin tinggi akhlak yang dimiliki siswa maka semakin tinggi pula hasil belajar Pendidikan Agama Islam yang diperoleh. Hal ini sejalan dengan pendapat Hamdani (2015) Akhlak atau kepribadian merupakan faktor yang cukup penting bagi keberhasilan seorang siswa dalam proses pembelajaran. Serta akhlak bisa menentukan apakah siswa tersebut menjadi siswa yang baik atau sebaliknya. Siswa yang memiliki pergaulan yang baik, penuh kasih sayang, perhatian, serta disiplin akan memiliki hasil belajar yang lebih baik. Sedangkan siswa yang memiliki masalah dan perbuatan yang kurang baik memiliki hasil belajar pendidikan agama Islam yang cenderung rendah.

Hasil belajar pendidikanaAgama Islam yang baik dapat diperoleh dengan sikap rajin, disiplin, ulet, semangat dan senantiasa mendekatkan diri kepada Allah SWT agar dimudahkan dalam menuntut ilmu dan dengan menerapkan indikator nilai-nilai akhlak sebagai seorang siswa, maka hasil belajar mereka akan meningkat.

Dari observasi awal peneliti di lapangan dan pengalaman selama meneliti di lapangan peneliti melihat masih terdapat akhlak siswa yang kurang baik seperti meribut di kelas, menganggu teman, berkata kasar, membantah perkataan guru dan lain-lain. Dari hasil analisis data dan hasil uji hipotesis yang dilakukan diperoleh ada hubungan yang signifikan dan positif antara akhlak siswa dengan hasil belajar Pendidikan Agama Islam. Hal ini bisa dipahami bahwa akhlak siswa ikut mendukung capaian hasil belajar Pendidikan Agama Islam.

\section{Simpulan}


Apriyanda dan Sulaiman: Hubungan Akhlak dengan Hasil Belajar pada...

Berdasarkan hasil penelitian yang telah dilakukan, maka dapat disimpulkan hubungan akhlak siswa dan hasil belajar mata pelajaran Pendidikan Agama Islam kelas VII di SMP Negeri 1 Sembilan Koto Kabupaten Dharmasraya tahun Ajaran 2020/2021 berada pada kategori sedang/ cukup baik. Artinya terdapat hubungan yang positif dan signifikan antara akhlak siswa dengan Hasil belajar Pendidikan Agama Islam siswa kelas VII di SMP Negeri 1 Sembilan Koto Kabupaten Dharmasraya tahun Ajaran 2020/2021. Hal ini dibuktikan dengan hasil analisis data dengan menggunakan rumus product moment diperoleh rxy 0,524. Sedangkan $r$-tabel dengan $n=60$ adalah 0,254 . karena $r$-hitung $(0,524)$ lebih besar dari pada r-tabel $(0,254)$, maka Ha diterima dan Ho ditolak. Artinya semakin baik akhlak seorang siswa maka semakin tinggi capaian hasil belajar Pendidikan Agama Islam siswa.

\section{Referensi}

Abuddin, N. (2015). Akhlak Tasawuf Dan Karakter Mulia (14th ed.). RAJAWALI PERS.

Afandi, M. (2013). EVALUASI PEMBELAJARAN SEKOLAH DASAR (1st ed.). UNISSULA Press.

Ahmad, H. (2020). Kajian Akhlak Dalam Bingkai Aswaja (N. Rosadi (ed.); 1st ed.). PT NARAYA ELABORIUM OPTIMA.

Ainiyah, N. (2013). Pembentukan Karakter Melalui Pendidikan Islam. Jurnal Al-Ulum, 13. https://doi.org/10.34005/tahdzib.v2i2.511

Arifin. (2011). Ilmu Pendidikan Islam (5th ed.). BUMI AKSARA.

Badrudin. (2015). Akhlak Tasawuf. In Akhlak Tasawuf (2nd ed.). IAIB PRESS.

Djaali. (2013). Psikologi Pendidikan. BUMI AKSARA.

Hamalik, O. (2012). Proses Belajar Mengajar (14th ed.). PT BUMI AKSARA.

Hamdani, Ulfah, M., \& Syahrudin, H. (2015). Hubungan Antara Kepribadian Siswa Dengan Prestasi Belajar Siswa Pada Mata Pelajaran IPS Terpadu kelas IX MTs. Muhammadiyah Sungai Bakau Kecil Kecamatan Mempawah Timur. Jurnal Pendidikan Dan Pembelajaran Untan.

Hasanah, S. (2017). Pembinaan Akhlak Siswa Berkebutuhan Khusus Melalui Kegiatan Ekstrakurukuler PAI Di SDLB Islam Yasindo Malang. J-PAI: Jurnal Pendidikan Agama Islam.

Izharman. (2018). Pendidikan Agama Islam Pembentukan Karakter Bangsa. Andalas University Press.

Jamal, S. (2017). Konsep Akhlak menurut Ibn Miskawaih. Tasfiyah, 1(1), 50. https://doi.org/10.21111/tasfiyah.v1i1.1843

Jumhuri, M. A. Al. (2015). Belajar Aqidah Akhlaq Sebuah Ulasan Ringkas Tentang Tauhid Dan Akhlaq Islamiyah. DEEPUBLISH.

Munirah. (2017). Akhlak Dalam Perspektif Pendidikan Islam. Jurnal Pendidikan Dasar Islam, $4(2), 39-47$.

Nurhasan. (2018). POLA KERJASAMA SEKOLAH DAN KELUARGA DALAM PEMBINAAN AKHLAK (Studi Multi Kasus di MI Sunan Giri Dan MI Al-Fattah Malang). Jurnal AlMakrifat, Vol 3, No.

Parwati, N. N. (2018). Belajar Dan Pembelajaran (1st ed.). RAJAWALI PERS.

Suyono, \& Harianto. (2012). BELAJAR DAN PEMBELAJARAN (A. S. Wardan (ed.); 3rd ed.). PT REMAJA ROSDAKARYA.

Wiratma, \& Wayan Subagia GL. (2016). PROFIL PENILAIAN HASIL BELAJAR SISWA BERDASARKAN KURIKULUM 2013. Jurnal Pendidikan Indonesia, Vol. 5. 